\title{
2 Struggles for energy transition in the electricity system in Asian countries
}

\section{A system complementarity perspective}

\author{
Akihisa Mori
}

\section{Introduction}

With rapid population and economic growth, the Asian region has increased its energy consumption. In response, policymakers have facilitated investments in fuel and power supply and infrastructure, focusing also on efficiency to ensure a secure, affordable, and more sustainable energy supply (IEA, 2019). However, an increase in fossil fuel consumption, especially coal consumption has resulted in worsening air pollution and increased greenhouse gas (GHG) emissions, which put heavy stress on local, regional, and global environments. To mitigate the stress the Paris Agreement requires Asian countries to prepare GHG emissions targets, to implement measures and policies as nationally determined contributions (NDCs), and to update pledges with more ambitious targets every five years.

The electricity sector has made the largest contribution to Asia's rising energy consumption and $\mathrm{CO}_{2}$ emissions. Electricity demand has substantially increased since the 2000s when Asian countries recovered from the 1997 economic crisis. It is projected to more than double by 2040, assuming the current, relatively low per capita electricity consumption, future economic growth, and future universal access to electricity. While a shift from traditional unsustainable and unsafe use of solid biomass to electricity would reduce indoor air pollution and health damage, it may not reduce $\mathrm{CO}_{2}$ emissions without an accompanying reduction in fossil fuel use within the electricity sector. To achieve more ambitious targets, a large-scale integration of renewable-energy-sourced electricity (RES-E) into the grid system becomes indispensable (Madrigal and Stoft, 2012).

Previous research has analyzed the shift in the energy mix mainly from economic efficiency, security of supply, and lock-ins. They have argued for favorable policy measures to address the high levelized cost of electricity (LCOE) for wider diffusion of wind and solar power (Aguirre and Ibikunle, 2014), such as a feed-in tariff (FiT) and renewable portfolio standard. When the cost of generating this energy becomes competitive around the world (IRENA, 2020) and a FiT is replaced with auctions (Dobrotkova et al., 
2018), the arguments go beyond its generation to address the challenges for network governance, such as integration costs (Hirth et al., 2015), as well as security of supply in order to address shrinking capacity margins. The coal lock-in perspective elucidates interdependent and mutually reinforcing effects among technological, economic, institutional, and behavioral lock-ins, arguing for the involvement and cooperation of actors from different sectors for unlocking (Seto et al., 2016). However, it is not sufficient to analyze the governance of networks in transitions.

Complementarities and competitions within and across a sociotechnical system can bring deeper understanding of the co-evolution of generation and network subsystems. They see a sociotechnical system as elements of complementarities that have their own dynamics, different time horizons, and speed of development (Markard et al., 2016), and technological limitations and asynchronous developments of each element as bottlenecks that slow down or impede a transition (Markard and Hoffmann, 2016).

Against this backdrop, this chapter explores how Asian countries have changed their energy mix in the electricity supply, with special attention to the restructuring of elements of complementarities within and across their electricity systems in energy switch from fossil fuel to RES-E.

The remainder of this chapter is organized as follows. Section 2 makes a literature review to propose an analytical framework for system change in electricity system from complementarity viewpoints. Section 3 overviews changes in energy mix in electricity generation in Asian countries, and Section 4 conducts case studies, taking Vietnam, Indonesia, India, and Japan as representatives of each typology of energy switch. Section 5 discusses commonly observed obstacles and challenges of the restructuring of elements of complementarities, and how foreign actors can accelerate or retard system transitions, causing carbon leakage, relocation, and halos. Section 6 concludes the chapter with perspectives for the following chapters.

\section{Analytical framework}

\subsection{Elements of complementarities in thermal-based electricity supply system}

Complementarities and competition in the fuel-intensive thermal electricity supply system can be illustrated as in Figure 2.1. The system has four types of complementarities along the supply chain: infrastructure, organizational, engineering and manufacturing, and institutional. These complementarities are not inherent to the thermal power supply system. Rather, they are built and strengthened to overcome bottlenecks and make the system work effectively.

Infrastructure complementarities are created to secure fuel transportation, and transmission and distribution networks, known as grids, that supply and deliver electricity. Under the centralized electricity system, grids 


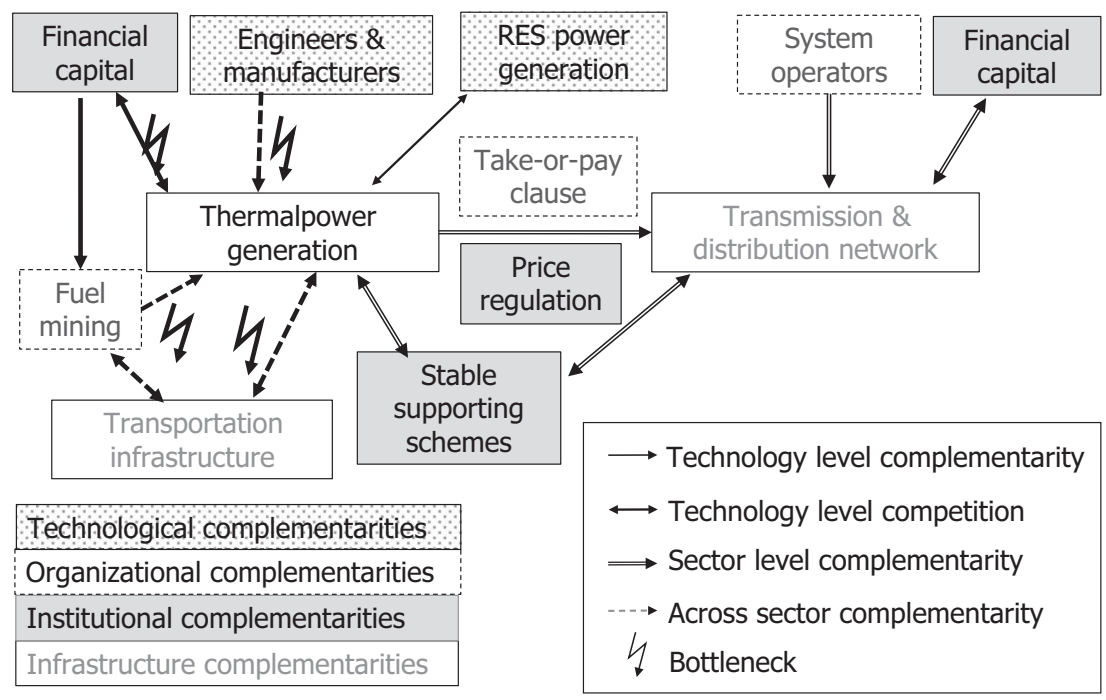

Figure 2.1 Complementarities and their bottlenecks in a fuel-based thermal electricity system

Source: The author.

have mostly been developed in response to individual interconnection requests from large-scale generation plants.

Engineering and manufacturing complementarities are created to engineer design, procure technologies, construct, operate, and maintain plants and grids. Fossil fuel power generation is a proven, standardized technology that requires less testing and qualifying processes (Tushman and Rosenkopf, 1992) and site-specific activities (Steffen et al., 2018). However, some countries do not have enough technological and managerial capabilities, especially for large-scale plants with the latest technologies, such as ultra-supercritical and integrated coal gasification combined cycle plants. Engineering and manufacturing complementarities also help electricity generators upgrade production technologies, provide an arena for testing and qualifying novelties to foster the ability of domestic industries, and establish an industrial network that has a number of technologies and linkages between subsystems (Tushman and Rosenkopf, 1992).

Institutional complementarities are created to secure financial capital. The electricity supply system is characterized by sunk investments, high entry barriers, long operating lifetimes, and complementary capital investments (Schmidt et al., 2017). These characteristics mean investments in the system are perceived as highly risky. To secure a stable revenue stream over the years, vertically integrated monopolistic or oligopolistic supply is employed under network regulations, focusing on short-term efficiency, 
competition, and a level playing field to restrict exploration of excess rent. Stable institutions, including those with consistent long-term demand-side policies, legitimacy, and alignment with practices in other sectors and regional/local institutions, are key systemic factors for rapid development and diffusion of a type of generation technology (Negro et al., 2012). By confirming institutions for cost recovery, bilateral donors and multilateral development banks provide long-term loans to implement turnkey projects that address technological and institutional bottlenecks simultaneously.

Organizational complementarities are created to minimize commercial risks and avoid sunk cost investments. They include a long-term fuel supply and a transportation contract that ensure a stable fuel supply for power plants at an affordable price, and a power purchase agreement with utilities that ensure stable sales of their products at a pre-determined price. Independent power producers (IPPs) and project developers work to arrange these contracts to close financial packages and to obtain concessions from authorities.

\subsection{Elements of complementarities in distributed, RES-based electricity system}

A substantial change in energy mix requires realignment of these elements of complementarities. The change is radical in the shift to RES-E because the shift requires a transformation not only from fuel-intensive to capitalintensive electricity generation but also from the existing hierarchical and centrally controlled electricity distribution networks toward a smart power grid paradigm, in which unforeseen peaks of distributed local electricity production and uncertainty of RES-E can be properly managed (Abrishambaf et al., 2019).

The electricity system based on the smart power grid paradigm has addressed challenges of cost-effective and proper grid operation and system balancing in three ways: sufficient network capacity and stronger transmission grids; greater storage capacity; and more flexible responses for system balancing (Gulagi et al., 2018; Newbery et al., 2018).

First, ultra-high-voltage, direct-current (UHV-DC) power transmission systems can improve stability, reliability, and transmission capacity. When developed and coupled with region-wide super-grids, the systems can deliver RES-E generators in remote, less populated areas to areas with higher consumption, and thus can reduce RES-E curtailment significantly (Burgholzer and Auer, 2016). Interconnectors can deliver back-up power when variable RES generators are unavailable (Neuhoff et al., 2013). Interconnection exploits differences in wind and solar conditions across regions, reducing supply variability. To develop grid capacity in a cost-effective manner, as well as to attract financing for grid development, existing transmission planning and cost allocation practices have to be revisited to collect network fixed costs in an efficient and equitable manner (Madrigal and Stoft, 2012). 
Second, storage offers back-up of RES-E, smoothing out of the variability of RES-E, shaving peak use, and deferring upgrades in transmission and distribution systems. Pumped storage plants have been constructed to deal with inflexible sources of electricity, thus accounting for the majority in the storage capacity. Battery technologies are emerging, offering a grid defection opportunity by mandated installation of rooftop solar photovoltaics (PVs), as well as allowing distributed generation in remote areas where expansion can be very costly and disruptive.

Third, an effective use of the existing network has been pursued to increase flexibility in the transmission grid as well as to reduce the need for network extension (Auer and Haas, 2016). Theoretically, an energy-only competitive wholesale market can satisfy most of the flexibility needs as long as it is equipped with centralized scheduling and efficient dispatch, frequent scheduling and settlement intervals (i.e. five-minute scheduling and settlements), and a make-whole payment guarantee providing incentives for generators that follow the prices (Ela et al., 2016).

Ultimately, smart grids would enhance flexibility, reliability, sustainability, and the efficiency of a distributed electricity supply system by making the grid controllable, automated, and fully integrated (Colak et al., 2016). Several enabling technologies and systems play decisive roles in facilitating the coordination of efficiency in a smart grid, such as smart meters, energy controllers, two-way communication systems, the merger of information and communication technology and electricity grids, intelligent and remote supervision, and Advanced Meter Infrastructure (Camarinha-Matos, 2016). These technologies and systems would constitute a basis for transactive energy systems that can better manage millions of distributed generators, consumers, and prosumers through transactive network management and control, and peer-to-peer management in smart grids without centralized regulators (Abrishambaf et al., 2019). They would enable a shift to more granular temporal and spatial prices and reduce the reliance on politically backed, long-term contracts and the capacity remuneration mechanism.

In practice, however, various market and policy failures make it difficult for a market to operate these programs alone. Generators do not always engage in the electricity market or respond to price signals because they conclude bilateral contracts and provide the market operator or utilities with the scheduled output at a pre-determined price. To incentivize such generators to engage in and offer their flexibility in the market, a number of market-based ancillary service markets have been created in day-ahead and real-time electricity markets. Recent technological developments in smart meters and automated demand controllers enable net metering to work, benefitting prosumers by reducing the charges to pay to the grid operator, and facilitating demand-response programs (Newbery et al., 2018). However, an energy-only market generates price spikes when capacity is tight because incumbent utilities exercise market power to drive up prices. Such a highly volatile electricity market means self-scheduling generators lose 
substantial profits and credibility from consumers (Ela et al., 2016). Wholesale price caps can limit their market power but reduces profitability of capacity investment, leading to underinvestment in the longer run. Direct load control, such as time-of-use and critical peak pricing, can bring flexibility to the grid by paying incentives to the electricity consumers in exchange for altering their consumption profiles (Siano, 2014). However, demand response is often limited and thus cannot sufficiently address the challenge (Cramton and Ockenfel, 2012).

The capacity remuneration mechanism is an alternative market designed to increase flexibility and to maintain an adequate capacity, simultaneously. It allows utilities to provide pre-specified load reduction in exchange for supplementary revenues. In particular, a forward capacity market with long-term contracts can provide the required adequate level and lower cost to consumers and more stable capacity prices, as compared to a yearly capacity market (Bhagwat et al., 2017). The mechanism is also expected to reduce fluctuations caused by investment cycles, and make market development more predictable (Bublitz et al., 2019).

However, a strategic reserve can have adverse effects on a large-scale integration of RES-E. Even if the capacity is determined by auction, the type and amount of capacity to be procured is critically dependent on government policy and the auction design. Incumbent utilities can exercise market power in capacity auctions (Schwenen, 2015). As a result, strategic reserve can stimulate stand-by generation capacity (Torriti, 2016) and new fossil fuel power plants, preventing existing ones from being decommissioned (Lehmann et al., 2015). In addition, it would make flexibility options, such as the demand-response programs and storage options, redundant (Auer and Haas, 2016).

In addition, both an energy-only market and the capacity remuneration mechanism cannot help centralized system operators manage millions of small-scale, distributed agents such as consumers, producers, and prosumers with distributed technologies such as rooftop solar PVs and electric vehicles (EVs), and are located in large geographical areas and do not have the capability to engage in the market and sophisticated smart grids.

Distributed energy resource aggregators would play a pivotal role in supplying RES-E and ancillary services in the electricity market by grouping such small-scale agents and technologies. They can also manage the uncertain behavior of the RES-Es in the real-time operation by closing information gaps, and coordinating distributed resource operations (Burger et al., 2017; IRENA, 2019). These aggregators are also expected to pool the generation and/or consumption flexibility of customers/prosumers at a low voltage level in the future (Lipari et al., 2018).

Corporate renewable power purchase agreements (PPAs) also help RES-E producers secure a revenue stream and access to project finances. Under a PPA, corporate customers purchase RES-E at a pre-agreed price for a pre-agreed period of time, and transfer environmental attributes. They can 
hedge against energy price volatility and reduce the cost of carbon in implementing sustainability strategies that go beyond purchasing renewable energy certificates (WBCSD, 2016).

\subsection{Challenges to the transitions to RES-E-based system}

The aforementioned arguments imply that a large-scale shift in energy mix to RES-E accompanies the restructuring of the elements of complementarities within the electricity system (Figure 2.2).

RES-E generators tend to employ RES-E technologies engineered and manufactured by dedicated manufacturers that are different from thermal power ones. RES-E technologies can generate technological and policy feedback effects (Jordan and Matt, 2014), improving and scaling domestic manufacturing technologies and processes through economies of capacity and scale to gain a competitive edge in both domestic and international markets (Hansen et al., 2019), and mobilizing support from increasing numbers of emerging beneficiaries to modify state capacities and institutions in favor of them (Mori, 2018c). They encourage the installation of storage and batteries to minimize loss from curtailment, and an emergence of business models, such as renewable PPAs and third-party ownership, thereby increasing customer and prosumer bases for RES-E (Ode and Wadin, 2019).

Deepening domestic capital markets enable capital-intensive energy projects to access private financial capital and increase their viability on a commercial basis (Best, 2017). Traditional formal financial institutions are

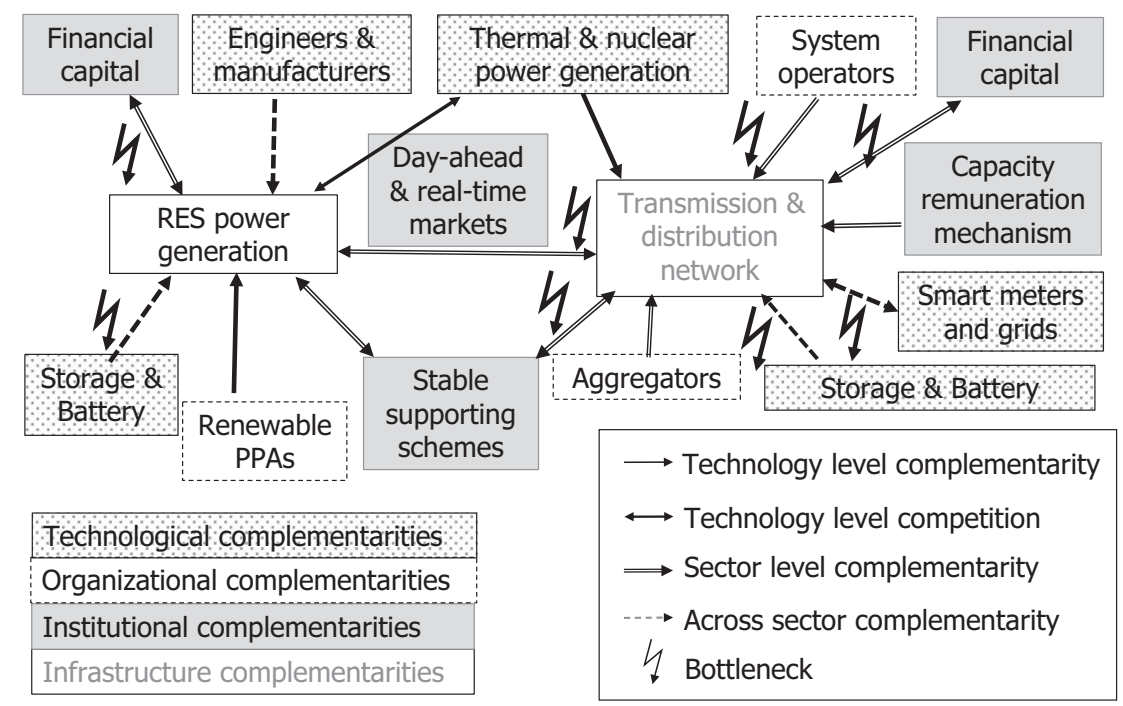

Figure 2.2 Complementarities and their bottlenecks in a RES-based electricity system

Source: The author. 
generally less willing to make loans for these new capital-intensive power generation plants, due to longer supply chains and longer pay-back periods (Haskel and Westlake, 2018). In particular, they are unwilling to do so for small and medium-sized energy enterprises, due to the high default risk, insufficient competition, poor guarantees, and a lack of information about their ability to repay loans (Haselip et al., 2013). However, pension funds and green banks are emerging as financial capital providers, thus overcoming financial bottlenecks (Rifkin, 2019).

Grids have to be enhanced to gain complementarities with a variety of types of generations located in wider geographical areas. This requires financial capital for enhancing grid capacity and system balancing. Direct load control, market-based ancillary services, and the capacity remuneration mechanism may be implemented to support centralized system operators to balance the system. Aggregators may emerge as organizations that provide connecting services for a mass of micro prosumers. Storage, batteries, and smart grids may help increase flexibility of grid operation.

On the other hand, a large-scale integration of RES-E will reduce utilization of the capital stock embodied in existing fuel-intensive electricity supply systems, weakening complementarities within and across the fossil fuel-based electricity system. First, coal, oil, nuclear, and combined cycle natural gas plants are required to be used as load following electricity, despite load following use of these power plants or lowering the power output is estimated to increase the LCOE (Hirth et al., 2015). This is particularly the case for nuclear power plants that are designed without having the load following capability and are composed almost entirely of fixed and sunk costs (Nuclear Energy Agency, 2011). The existing installed capacity of thermal power will become idle or spinning reserves, generating extra costs for maintenance. The loss associated with these stranded investments becomes prohibitive for recently installed capacity because they are forced into early retirement, leaving the majority of capital investments unrecovered.

Second, demand for fuel, transport infrastructure, and engineering and manufacture services, and financial capital will decrease as thermal power plants become stranded assets. These goods and service providers are urged to find alternative profit opportunities in other countries or business fields, or risk becoming stranded.

These adverse distributional impacts motivate incumbent utilities and thermal power generators to exercise economic, political, and cognitive power to block thermal power load from being used as a load following generation plants. They may lobby the government to block RES-E generators from obtaining finance in the capital market (Lockwood et al., 2019). Grid companies may impose high fees for transmitting RES-E, and even admit priority access to coal power to RES-E (Mori, 2018c) while deterring investments in grid capacity and flexibility.

Stable institutions can narrow opportunities for change and restrict development of bottom-up solutions (Baker et al., 2014). They enable incumbent 
regime actors and governing elites to enhance and expand coalitions (Mori, 2019), influencing decisions and political goals in their favor (Meadowcroft, 2011), and create high entry barriers (Stirling, 2014).

In addition, long-term, take-or-pay clauses stand as institutional lock-ins, working to maintain the existing complementarities within and across the fuel-intensive electricity supply system. In particular, take-or-pay clauses in long-term PPAs force grids to offer priority access to coal IPPs, and usually remain unchanged (Burke et al., 2019). They protect thermal power plants from becoming stranded even if RES-E achieves grid parity, thus forcing renewable curtailment.

\section{Methodology and case selection}

We use the restructuring of elements of complementarities as a framework to explore the choke points of system transformation, and the possible role of foreign actors in accelerating and retarding them. The logic of this selection is that an increasing number of Asian countries encounter renewable curtailment that calls for the transformation of the grid system to fix it, and that a whole system perspective that encompasses interdependencies between generation and network subsystems becomes important to avoid bottlenecks in the acceleration phase of energy transitions (Bauknecht et al., 2020).

We adopt a case study strategy because case studies are rich in context and can track complex developments over time (George and Bennett, 2004). Given that Asian countries are diverse in energy resource endowment and have taken varied pathways to coal-based electricity supply systems, we make a preliminary analysis on energy transitions in these countries for case selection.

\section{Transition in energy mix in power generation in Asia}

\subsection{Cluster analysis}

Most of the Asian countries-26 countries in Northeast, Southeast, South, and Central Asia in this chapter-used domestically available energy resources to increase electricity supply at the outset of economic development. Initial endowment of energy resources is varied among them. Some countries are rich in multiple energy resources, others are rich in only one of them, and the rest have to rely almost all their energy resources on foreign countries.

They can be grouped into four categories by domestically available energy resources.

The first group is oil- and gas-rich countries. They are Bangladesh, Brunei, Indonesia, Malaysia, Myanmar, Turkmenistan, and Uzbekistan. Some of them establish state companies to exploit oil and gas, gaining resource 
rent in the form of resource revenue, and distribute it widely to the public in the form of subsidized prices to maintain the legitimacy of governing elites. Others give concessions to domestic and international companies with ample technological and financial capacity, gaining resource rent in the form of corporate income tax, and spend it in a more transparent manner (Luong and Weinthal, 2010).

Many countries in this group rely on domestic natural gas and oil for electricity generation. Some of them continue to rely on them. In Brunei and Turkmenistan, natural gas and oil account for almost $100 \%$, and Uzbekistan more than $80 \%$, in 2018 (Figure 2.3). Others have switched to other sources of energy due to foreseeing a depletion of domestic oil resources in Malaysia and Indonesia, and to export contracts under resource backed loans or resource backed infrastructure schemes (Beardsworth and Schmidt, 2014).

The second group is water resource-rich countries. They are China, India, Indonesia, Japan, Laos, Malaysia, Pakistan, Tajikistan, and Vietnam, and to a lesser extent Kyrgyzstan and Myanmar (International Hydropower Association, 2020). Hydropower used to be the only source of energy for electricity generation for fossil fuel poor countries. In the 1990s, some countries, such as Laos, Nepal, Sri Lanka, and Tajikistan, relied on hydropower for all of their electricity supply, and others, including Kyrgyzstan, Vietnam, and Myanmar, relied on it for half of their supply. While Kyrgyzstan, Tajikistan, and Nepal still rely mostly on hydropower, Laos has decreased its reliance to two-thirds, and Sri Lanka, and Vietnam to one-third, in 2016-2018 (Figure 2.4). They have increased their installed capacity of coal power to satisfy the growing demand.

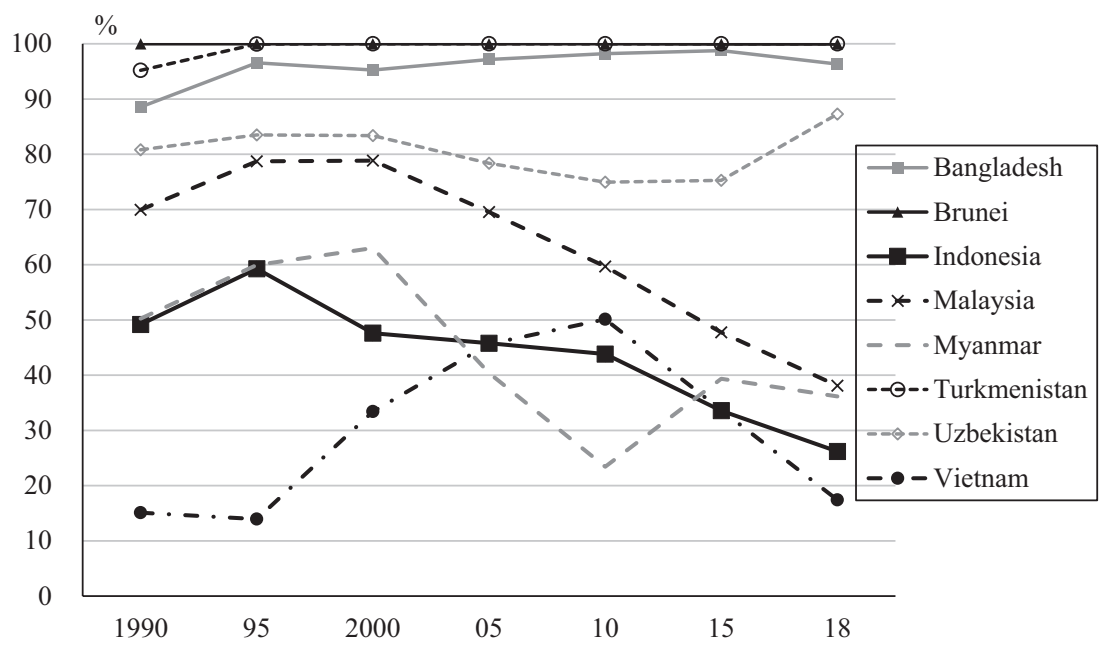

Figure 2.3 Electricity production from oil and gas in total production. Source: Compiled by the author based on the data from World Bank (2020). 


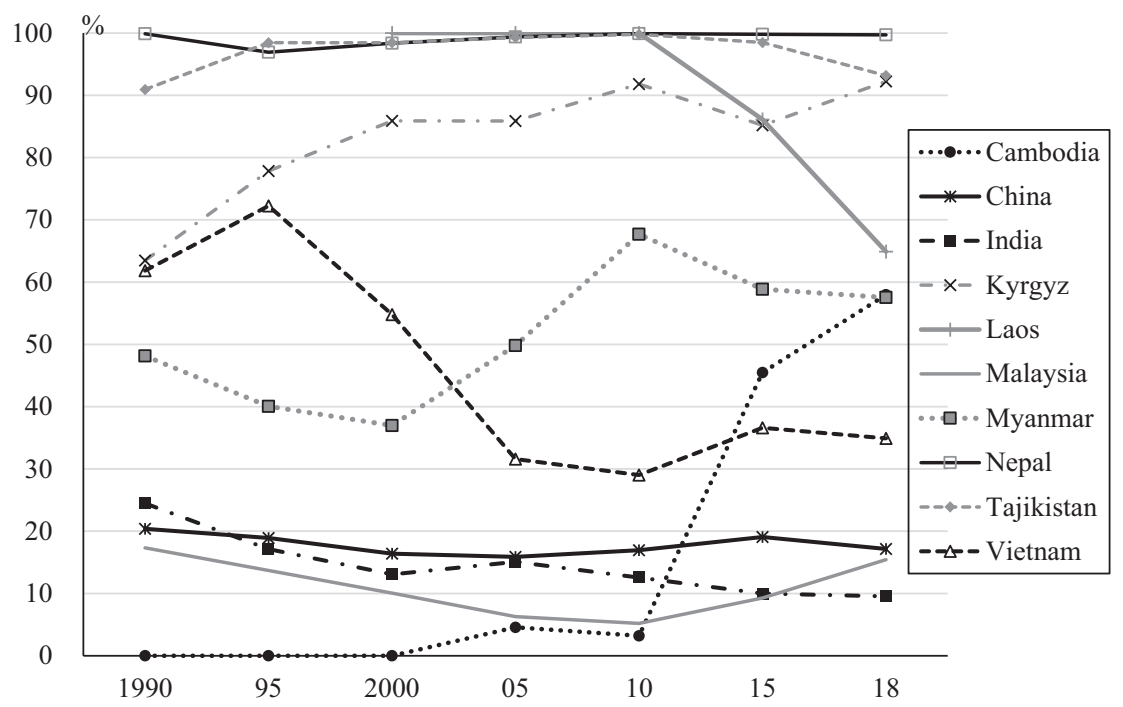

Figure 2.4 Electricity production from hydropower in total production. Source: Compiled by the author based on the data from World Bank (2020).

Decreasing reliance on hydropower does not imply that these countries will stop hydropower development. China has the largest installed capacity in the world and is competing with Brazil to be the world's leader in new capacity installation. India has also increased new capacity, surpassing Japan in total installed capacity in 2018 (International Hydropower Association, 2020). Vietnam, Laos, and Cambodia have developed hydropower along the Mekong River basin, Myanmar along the Salween River basin, Malaysia in Borneo, and Indonesia in Java, Sumatra, and the Sulawesi Islands (International Hydropower Association, 2018, 2019, 2020).

The third group is coal-rich countries. Although coal is an easily accessible and low-cost energy resource for most of the Asian countries, China, India, and Vietnam are the largest producers. Therefore, it is rational that coal power has played a dominant role in electricity generation in China and India (Figure 1.2). Vietnam experienced a steady increase in the ratio of coal power in the 2000 s, from $12 \%$ in 2000 to $30 \%$ in 2015.

Indonesia joined this group in the 2000s. When perceiving depletion of oil and stagnant development of new natural gas depots, the country shifted the focus on energy development toward coal mining. Coupled with the local autonomy, a number of concessions have been given to domestic developers for exports and domestic consumption (Mori, 2018b). The ratio of coal power in total electricity generation has increased from $24 \%$ in 1995 to $36 \%$ in 2000, and 56\% in 2015 (Figure 1.2). 
The last group is modern renewable energy-rich countries. The Philippines, Indonesia, and Japan have large potential for geothermal energy. However, the speed of development has been slow so far, due to high financial, technological, and institutional barriers. Geothermal energy is capital intensive in nature, requiring large amounts of initial capital. Higher development risks in exploring wells and unpredictable quality may create cost overrun, despite recent technological developments and increased accuracy of exploration (West Japan Engineering Consultants, Inc., 2007). Unpredictable and irreversible adverse impacts delay drilling permits, thus increasing financial risks (Kubota et al., 2013), especially where appropriate land use and spatial planning policies, streamlining permitting and environmental impact assessment processes, and studies on environmental and social impacts are lacking (Haukkala et al., 2021).

\subsection{Changes in energy mix in electricity sector}

The aforementioned mapping indicates that most of the Asian countries have gradually shifted their energy mix from easily accessible domestic energy resources to coal. They have accelerated the shift since the 2000s. Some countries have simultaneously developed hydropower but have turned to coal power much faster and on a much larger scale.

An increased accessibility to coal, financial capital, and engineering and manufacturing capabilities enables Asian countries to accelerate the energy shift. An increase in coal exports by Indonesia, Australia, Mongolia, and Kazakhstan (Mori and Dong, 2018) enables energy-poor Asian countries to access coal for electricity generation at an affordable price. This is particularly the case in Cambodia and Lao that have seen rapid increased coal imports for electricity generation (Figure 1.3). Vietnam has also rapidly increased coal imports since 2015 when it perceived a depletion of its domestic reserve. Other Asian countries added coal imports along with the expansion of coal power plants: India in 2009-2013, Malaysia and Thailand in 2000-2016, and the Philippines and Pakistan since 2014. International IPPs become more active in packaging financial, technological, operational, and fuel supply contracts in order to join the bidding and to gain concessions under PPAs (Mori, 2020).

In the 2010s, an increasing number of Asian countries began to shift their energy mix toward modern RES. In addition to the geothermal energy-rich countries of the Philippines and Indonesia, Thailand, Japan, India, and China have accelerated the shift, becoming top runners in the region. They increased the ratio of RES by around $10 \%$ in their total electricity generation in 2018 (Figure 2.5). Mongolia has rapidly increased RES since 2013 to diversify energy mix that had been exclusively relying on domestic coal. Pakistan, South Korea, and Sri Lanka can be categorized as followers with the ratio of RES at around 3\%-4\%, and Cambodia and Malaysia as laggards with a ratio of $1 \%$. 


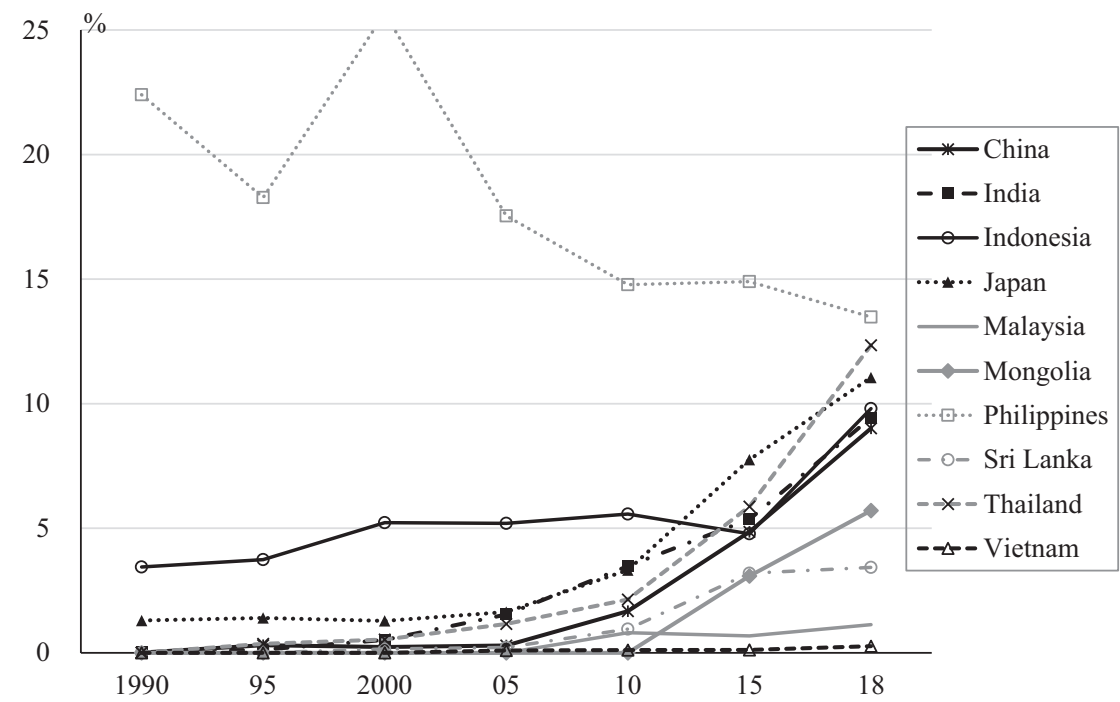

Figure 2.5 Electricity production from RES-E in total production. Source: Compiled by the author based on the data from World Bank (2020).

Behind the boost of RES-E in Asia, there are favorable renewable energy policies and decreasing LCOE. An increasing number of Asian countries have implemented a FiT, ambitious RES targets including ones specific to wind, solar, and geothermal, and priority grid access (REN21, 2020). LCOE from RES has been going down steadily (REN21, 2018: 119). The global shift to tenders is driving down the cost of wind power for utilities and ratepayers, prompting wind turbine manufacturers to look for ways to further reduce their costs and consolidate the industry (REN21, 2018: 115). The manufacture of components, assembly, and company offices are spreading to be close to growing markets in wind energy. Capacity factors are increased by scaling size of machinery. Combined solar and wind projects at the same interconnection prevail to reduce equipment, siting, grid connection, financing, and operations and maintenance costs (REN21, 2020: 140).

Given the substantial differences between coal-based and RES-based electricity supply systems indicated in Section 2.3, the simultaneous increase in coal and RES in energy mix triggers serious conflicts of interest, resulting in a large-scale curtailment (Mori, 2018c). Although countries with large production capacity of RES-E components increase exports to mitigate the conflict, this strategy has triggered repercussions in the importing countries. The United States imposed anti-dumping duties on Chinese and Taiwanese crystalline silicon solar panels in 2011 and 2015, expanding to uniform tariffs to cover all the imports including those from Malaysia, Korea, and Vietnam in 2018 (Nguyen and Kinnucan, 2019). India also imposed 
anti-dumping duties on imports of a certain type of sheet used in solar cell making from China, Malaysia, Saudi Arabia, and Thailand for five years to safeguard domestic players against cheap shipments (The Economic Times, 2019).

\subsection{Case selection}

A varied energy endowment and transition pathway in the preliminary analysis suggest that no country can represent energy transition in Asia. Nonetheless, we pick up four countries as representatives in each cluster that went through the transition pathway from coal-based to RES-based electricity supply systems. Vietnam is selected as a representative of countries rich in water resources and going through an energy shift in a short period of time. Indonesia represents oil- and gas-rich countries going through an energy shift to coal when perceiving depletion. India represents coal-rich countries with strong coal lock-ins, and Japan with strong nuclear lock-ins.

\section{Case studies}

\subsection{Vietnam}

Vietnam's electricity sector is dominated by large state-owned enterprises. Vietnam Electricity (EVN) fully controls grid systems and accounts for two-thirds of the installed capacity. Other large state-owned enterprises (Vinacomin and Petrol Vietnam), joint stock companies, and other domestic investors own the rest (Neefjes and Dang, 2017). Energy mix in the sector has been changed from hydropower to natural gas, and then to coal during the last three decades. When the country became a net-importer of coal in 2015, a reduction of the fiscal costs of imported coal (in a state-owned power generation system) became an important policy objective (Zimmer et al., 2015). In addition, serious air pollution triggers local protests against new coal power (Do et al., 2020).

In response, the government set ambitious renewable targets by type of sources, revised the National Power Development Plan VII (PDP-7) to shift the priority on RES-E development, accepted IPPs, and implemented a generous FiT for onshore wind in 2011, biomass in 2014, and scale and rooftop solar PVs in 2017, as well as tax exemptions. The FiT directed investments in RES-E, thus increasing its ratio in installed capacity in 2015 (Figure 2.6a). In particular, it boosted investments in utility-scale installations in 2019, making its installed capacity exceed the rest of ASEAN countries combined (Shani, 2020).

However, RES-E generation has not been scaled to be commensurate with the installed capacity. Except for hydropower and biomass, renewables accounted for less than $1 \%$ of total electricity generation by 2018 (Figure $2.6 \mathrm{~b}$ ). The strong control of retail electricity price discourages EVN from offering bankable PPAs and grid access to utility-scale solar project developers 


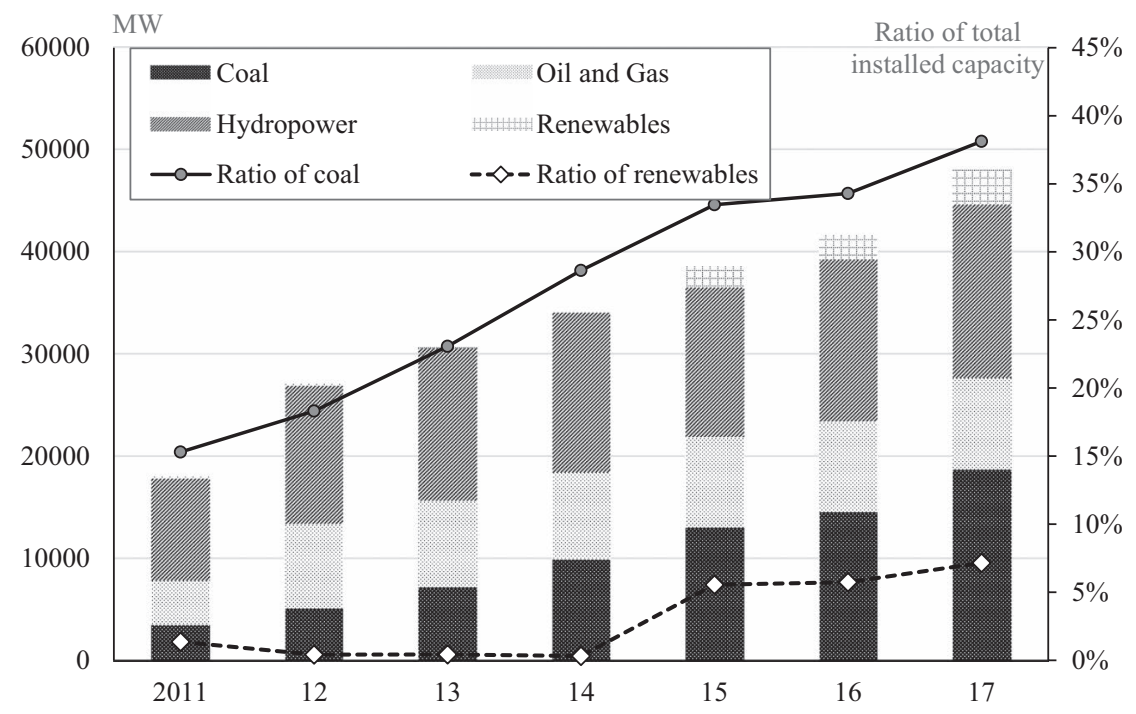

Figure 2.6a Energy mix in installed power generation capacity in Vietnam in 2011-2017.

Source: Compiled by the author based on the data from Vietnam Electricity (2012-2018).

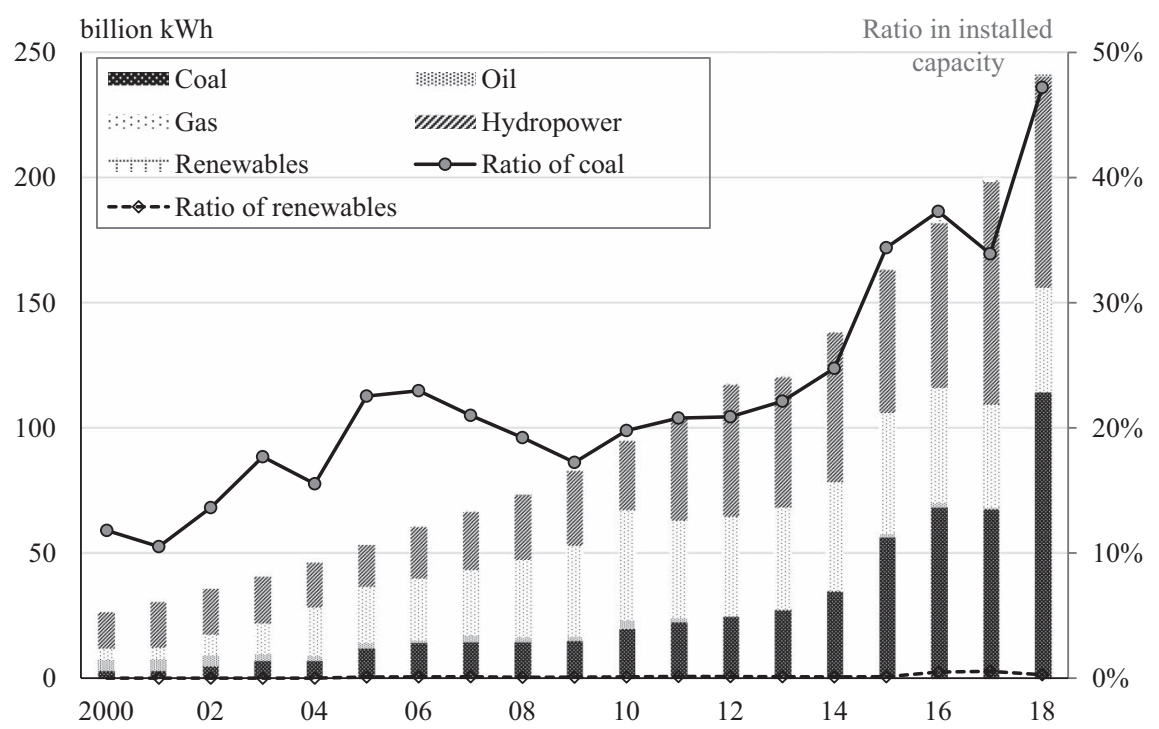

Figure 2.6b Energy mix in power generation in Vietnam in 2000-2018.

Source: Compiled by the author based on data from IEA (2021).

(Breu et al., 2019). Coupled with the geographical imbalance in demand and supply, insufficient financial capital for grid capacity development triggered solar curtailment (World Bank, 2019). Although the government lowered 
the feed-in tariff in 2019 and planned to replace the FiT with reverse auction (Government of Vietnam, 2020), inflexible updates under the Planning Law of 2019 delays the government's investments in grid capacity. Tightened public borrowing and abolishment of government guarantees make it difficult for the government to access international funding, further exacerbating the incompatibility between RES-E installed capacity and grid systems (Do et al., 2020).

\subsection{Indonesia}

Indonesia's electricity sector is characterized by the vertically integrated state-owned utility that is permitted monopolistic supply with a number of IPPs. It has four major transmission networks with limited interconnections within and across them.

To address interrelated challenges of insufficient generation causing frequent blackout, peaked oil production, increased energy subsidy squeezing fiscal resources for infrastructure development, and its induced demand growth in the early 2000s, the government released the Fast-Track Program (FTP-I) to increase installed capacity of $10,000 \mathrm{MW}$ by coal power, which was perceived as a readily available, accessible, affordable, and less vulnerable source of energy source (Reshetova, 2019). In the process, the country has strengthened complementarities in the coal-based electricity supply system (Mori, 2020). Initially, the government provided full guarantee to the credit risk of the state-owned utility in engineering, procurement, and construction contracts. To change the unfavorable terms of conditions, it allows foreign shareholding of IPPs with electricity business licenses and accepts take-or-pay clauses in PPAs with IPPs to secure financial packages. It imposes a domestic market obligation regulation, designates low-quality coal as the design coal for coal power plants (Best, 2017), and invests in ports, roads, and railways for coal transport to secure stable coal supply at an affordable price.

These newly created complementarities deter the government from implementing policies and developing institutions for a large-scale integration of RES-E, despite having large potential that could be used for pumped hydro energy storage (Blakers et al., 2018). The accelerated increase in coal power generation triggers power surplus, especially in the Java-Bali grid system (Kennedy, 2018). The take-or-pay clauses in PPAs may force the state electricity company to pay for unnecessary electricity when additional generation capacity is added in the system. The amount of such payments becomes significant once RES-E becomes cheaper than coal power generation. This poses the risk of the state-owned utility becoming incapable of investing in grid management and rationalization of electricity supply across regions (Burke et al., 2019). To save the distress of the state-owned utility, the government implemented a series of policy measures that would make renewable investments unviable (Setyowati, 2020) and the renewable 
target in the electricity generation in the 2014 National Energy Plan unachievable. These measures include a cap of the RES-E purchase price at $85 \%$ of the state-owned utility's average local generation cost; reduction of the price of exports from solar power generators to $65 \%$ of the company's applicable retail price (Hamdi, 2019); and replacement of a FiT with reverse auctions under a build-own-operate-transfer basis that impose takeover risks of the land for utility-scale solar power generation (Burke et al., 2019). However, neither the government nor the state-owned utility has enhanced grid capacity.

As a result, installed capacity of coal power increased by $10 \mathrm{GW}$ in 2011 and exceeded $30 \mathrm{GW}$ in 2019, while that of RES-E did so by $1.5 \mathrm{GW}$ in 2013 and has slightly increased since then (Figure 2.7a). Accordingly, coal accounts for a greater portion in electricity generation, exceeding $60 \%$ in 2017 , replacing oil, while RES-E remains a minor portion (Figure 2.7b).

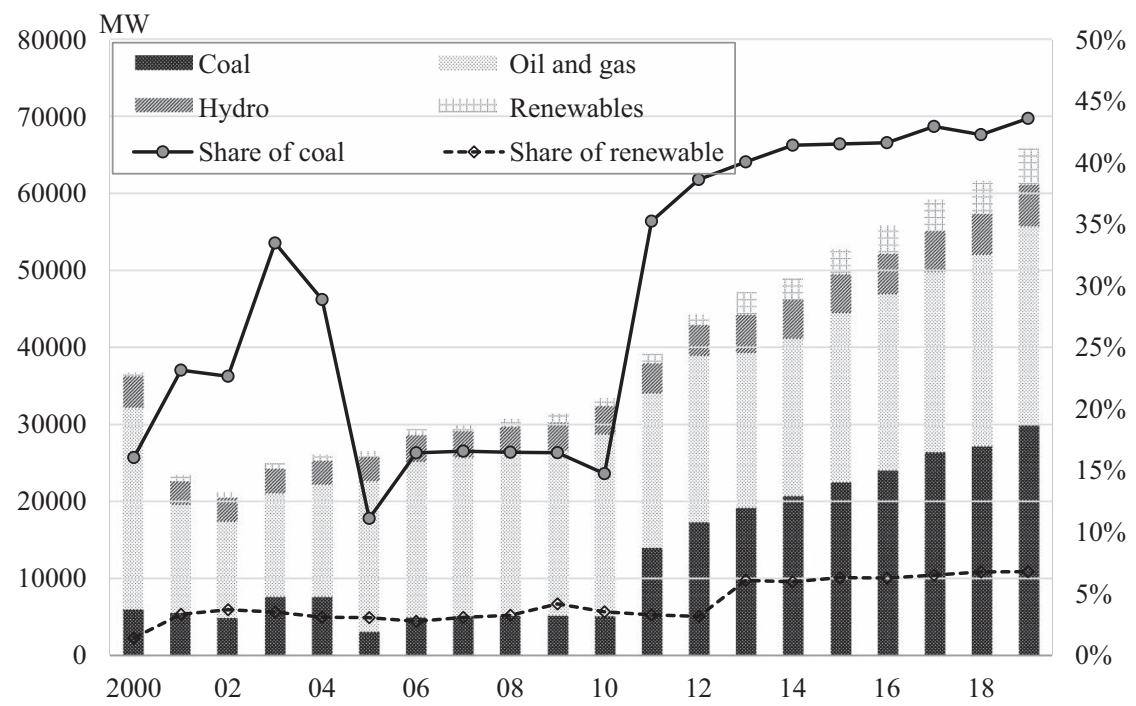

Figure 2.7a Energy mix in installed power generation capacity in Indonesia in 2000-2019.

Note:

1 Renewable includes large, mini and micro hydropower, geothermal, wind, solar PV, and biomass power.

2 In Indonesia, PLN and Ministry of Energy and Mineral Resources publish statistical yearbook of electricity. However, there are slight discrepancies between them, and both update a series of data in later years, which makes it difficult to analyze with consistent data. In addition, PLN annual reports are accessible only in 2014-2018, which is narrower than the scope of this paper. For these reasons, this paper takes the data from the Ministry of Energy and Mineral Resources because it provides disaggregated data for many years, which enables to trace source of energy.

Source: Compiled by the author based on the data from Kementerian Energi dan Sumber Daya Mineral. 


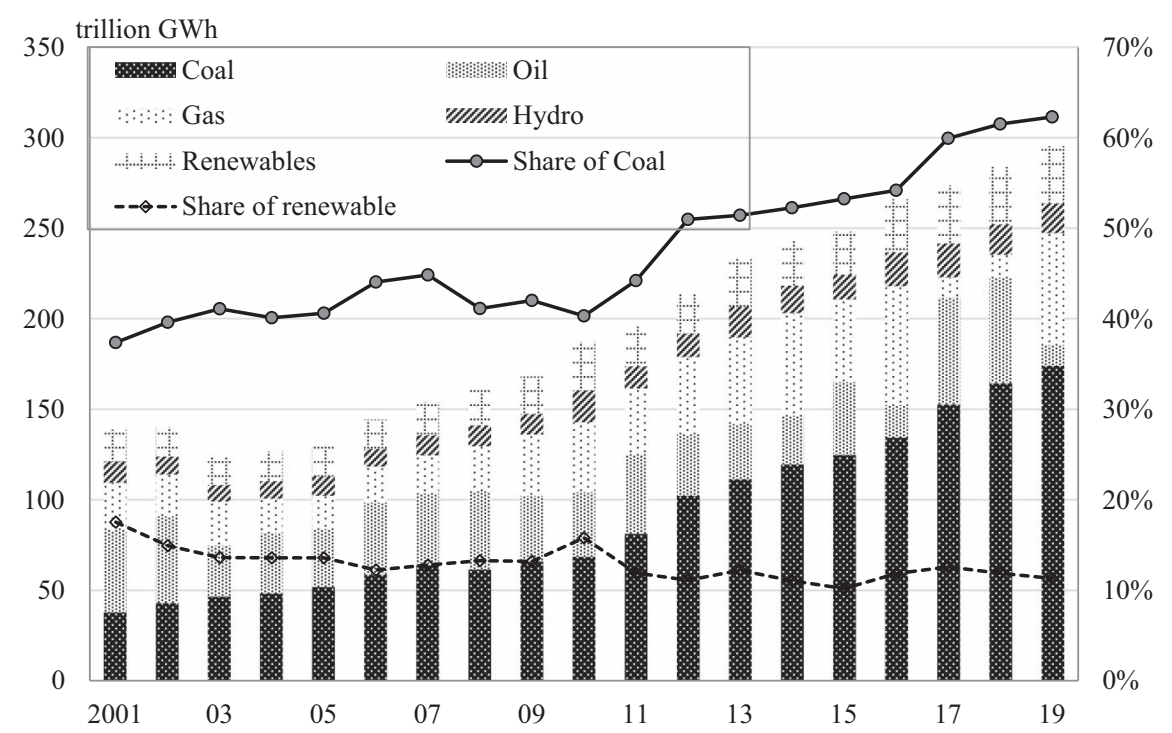

Figure 2.7b Energy mix in power generation in Indonesia in 2001-2019.

Source: Compiled by the author based on the data from Kementerian Energi dan Sumber Daya Mineral.

\subsection{India}

India's electricity system is characterized by the strong complementarities within and across the coal-based electricity system, rapid growth in RES-E generation, and a nationwide network of transmission lines with inefficient operation.

The strong complementarities within the coal-based electricity system originate from the coal linkage system among domestic coal mining, national railway, and coal power plants. To guarantee fuel supply for the life of coal power plants and complementary capital investments in coalmining, the State Energy Board specifies that coalmining supplies coal to a coal power plant through a fuel supply agreement (Chandra, 2011) and designates national railways for transportation. On top of the system, a large number of coal powers have concluded long-term PPAs with state utilities responsible for distribution and sales, despite the creation of day-ahead and real-time electricity delivery markets. New power plants are designed to accept domestically produced, low-quality coal that generates heavy air pollution and fierce protests against new power plants. Despite this, the country has developed technological capabilities for engineering the latest plants with fewer emissions (Mukherjee and Chakraborty, 2015).

The complementarities have been entrenched by large vested interests. Coal provides not only benefits for energy security but also jobs for a 
massive number of the labor force, and royalty revenues for most of the central and eastern region states, becoming a source of political support (Vishwanathan et al., 2018). Fossil fuel and on-grid electricity subsidies (Burke et al., 2019) and cross-subsidy to railway passengers (Carl, 2015) are also entrenched to satisfy persistent demands for social gains (Kale et al., 2018). These entrenched complementarities have created large, vested interests, constraining policymakers and state utilities from diverting these subsidies for renovation and upgrade of the deteriorated transmission and distribution networks (Kale et al., 2018).

As a result, the gap between demand and supply rose to $10 \%$ in $2009-2010$ (Ministry of Power, 2020). The serious gap directed the government to boost RES-E as a politically sustainable option to increase installed capacity. The government has developed institutions and implemented policies favorable for RES-E development. They include establishment and upgrade of dedicated ministry, financial institutions, and research institutes for renewable energy; the Electricity Act 2003 that ensured complete participation of private producers; national wind and solar targets and renewable purchase obligation targets; a FiT and "reserve" power package, and its replacement with reverse auctions to take advantage of technological improvements and economies of scale in global solar PV production; development and operation of solar parks coupled with long-term PPAs to winning bidders (Chawla et al., 2018); and handling environmental impact assessments (EIA) and other administrative procedures as a part of auctions (Dobrotkova et al., 2018) that addressed uncertainties over land access, transmission connections, and regulations. Following Gujarat and Rajasthan, many states implemented their own complementary solar policies (Tarai and Kale, 2018). All of these institutional supports reduce renewable power pricing and financial costs, making access to bank loans easier (Thapar et al., 2018) and incentivize investments in RES-E projects. The repowering policy in 2016 upgraded engineering complementarity by mandating the replacement of aging wind turbines with more modern and powerful units (Kumar and Majid, 2020).

In addition, national grid interconnectivity has been improved under the One Nation-One Grid initiative and a Green Energy Corridor scheme. Utility-scale solar and wind developers are allowed to waive payment of interstate transmission charges (Dibyanshu and Rastogi, 2020). These elements of infrastructural complementarity enable developers to deploy solar and wind power in high-resource locations, and the electricity system to gain more flexibility.

Capitalizing on these favorable institutional and infrastructural environments, developers with access to finance in favorable terms win bids in competitive renewable energy auctions, dominating the RES-E supply (Dutt et al., 2019). As a result, new solar and new wind installations exceeded new coal installations in 2017, and new solar installations exceeded new wind installations in 2019 (Figure 2.8a). The ratio of solar and wind generation 


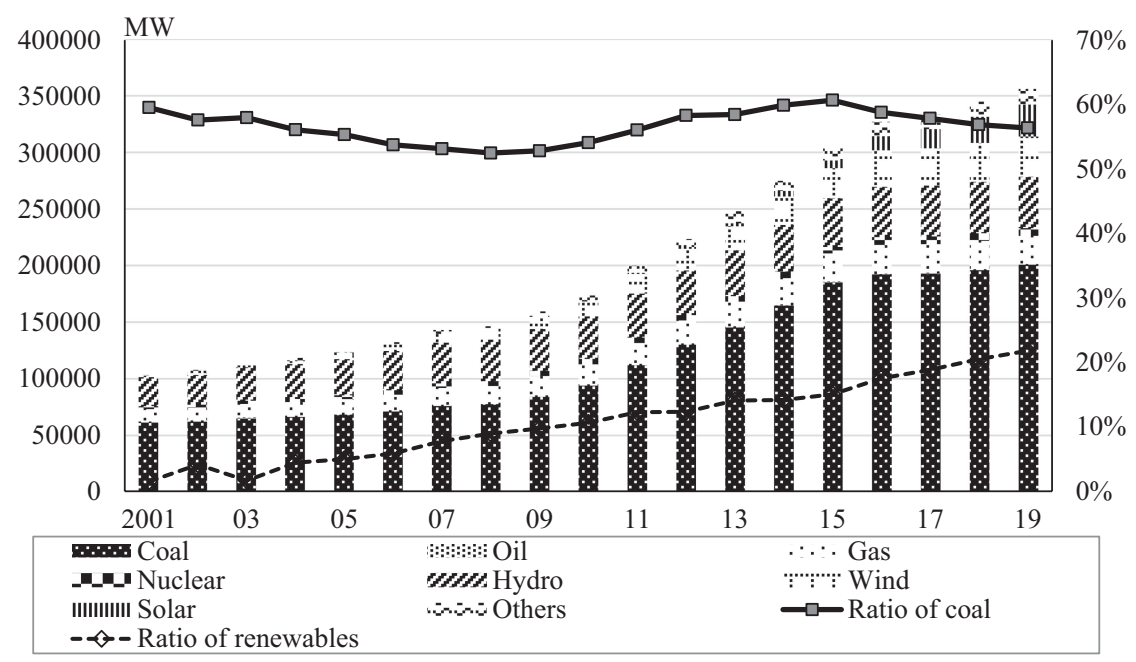

Figure 2.8a Energy mix in installed power generation capacity in India in 2001-2019. Source: Compiled by the author based on data from Ministry of Power, Annual Report, (from 2001-2002 to 2018-2019), https://powermin.nic.in/en/content/annual-reports-year-wiseministry\#/, accessed on 10 October 2020.

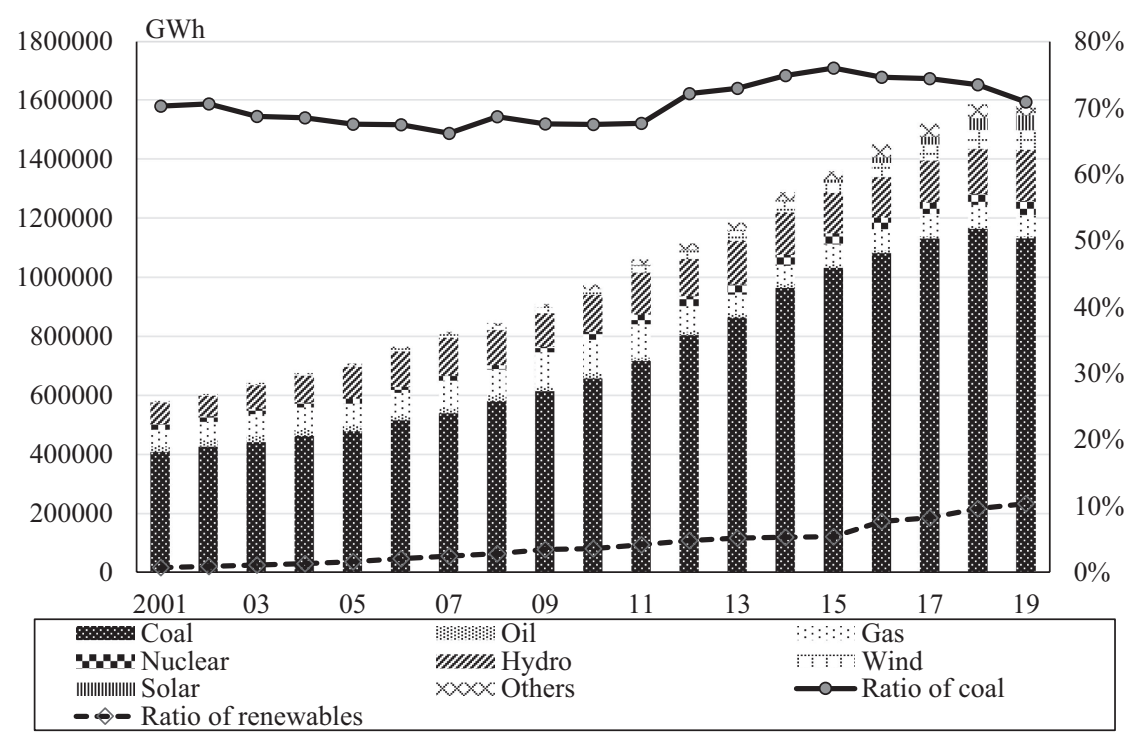

Figure 2.8b Energy mix in power generation in India in 2001-2019.

Source: Compiled by the author based on the data from IEA (2021). 
exceeded $10 \%$ in 2019 , filling the demand-supply gap and making that of coal power hit its peak in 2015 (Figure 2.8b). However, reverse auctions have intensified market concentrations to top developers who can undercut the competition consistently through foreign private equity investments, lower cost foreign debt, balance-sheet strength, or by virtue of being state-owned enterprises. Market uncertainties around the impact of the goods and services tax (GST) and the imposition of trade duties on imported solar modules, and the related impact on tendered projects under construction, reduce the number of developers sanctioning new capacity, further increasing market concentration (Chawla et al., 2018).

\subsection{Japan}

The Japanese electricity supply system is featured by a vertically integrated, centralized, nuclear, and liquidated natural gas-based one. Ten private electric power companies are permitted regionally monopolistic electricity supply in exchange for responsibility for security of supply and under the price regulations. The country has a nationwide network of transmission lines but is not sufficiently interconnected across their region service areas due to the differences in standard frequency and limited transmission capacity between the islands.

The centralized regionally monopolistic supply system has been reinforced since the 1970s when the oil crises pushed the Liberal-Democratic Party, the party in government for most of the period after World War II, and the ministry in charge, as well as the private electric power companies, to choose nuclear power as an alternative to oil, and to diversify sources of energy. To quell local protests, the government set up a dedicated earmarked fund to subsidize local governments that accepted the location of new nuclear power plants. To secure profit from nuclear business, it developed a nuclear fuel cycle and burdened backend costs, and limited competition among these private electric power companies by deferring investments in grid interconnectivity, leaving the choke points of the nationwide grid system unaddressed. It also encouraged Japanese manufacturers to obtain licenses on reactor engineering and manufacturing in order to enhance technological capabilities, and research institutes to develop technologies (Yamaoka, 2015).

The Party, the ministry, the electric power companies, and reactor manufacturers organized the pro-nuclear coalition, increasing spending for propaganda to tame the media and populace (Honma, 2016), and capitalized on the Kyoto Protocol to justify nuclear power (Mori, 2019). While the country had the largest capacity for solar PV manufacturing in the late 1990s, the coalitions propped up pressures against wider deployment of off-grid 
rooftop PVs, preventing solar PV manufacturers from taking advantage of scale economy to enhance market competitiveness.

The Fukushima nuclear disaster, coupled with the global financial crisis in 2008-2009, opened a window of opportunity for RES-E to emerge. Nuclear power lost credibility and suspended operations until safety was proved against the more stringent safety regulations, and until the government committee, local governments, and residents living nearby had been convinced to recommission the plants. To reconcile satisfying electricity demand and more stringent climate targets, the government's 2014 Strategic Energy Plan called for RES-E to account for 22\%-24\% of electricity generation by 2030 . The incumbent electric power companies were legally unbundled and the retail market was liberalized to increase competition in generation and distribution. As a result, renewable investments were boosted, and RES-E accounted for $6 \%$ in installed capacity and $9 \%$ in total electricity generation in 2018 (Figures 2.9a and 2.9b).

However, the country has left the restructuring of complementarities for larger integration of RES-E unaddressed. The levelized cost of wind and solar power remains less competitive due to higher cost of invertor and installation required to satisfy Japanese consumers' high demand for reliability (IRENA, 2020), a lack of clearly defined land use regulations, and unclear

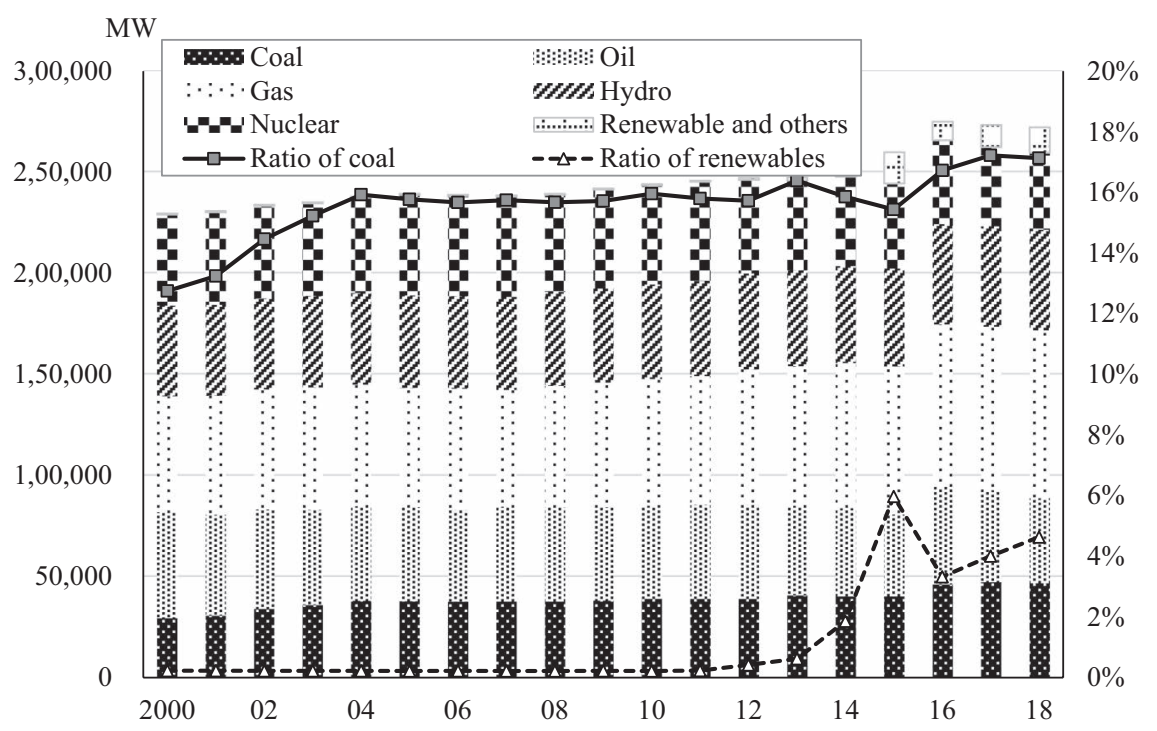

Figure 2.9a Energy mix in installed power generation capacity in Japan in 2001-2018.

Note: There is an inconsistency in dataset between the year 2015 and 2016 due to the difference in the coverage of the original database that the source refers to.

Source: Compiled by the author based on data from Federation of Electric Power Companies of Japan (2019). 


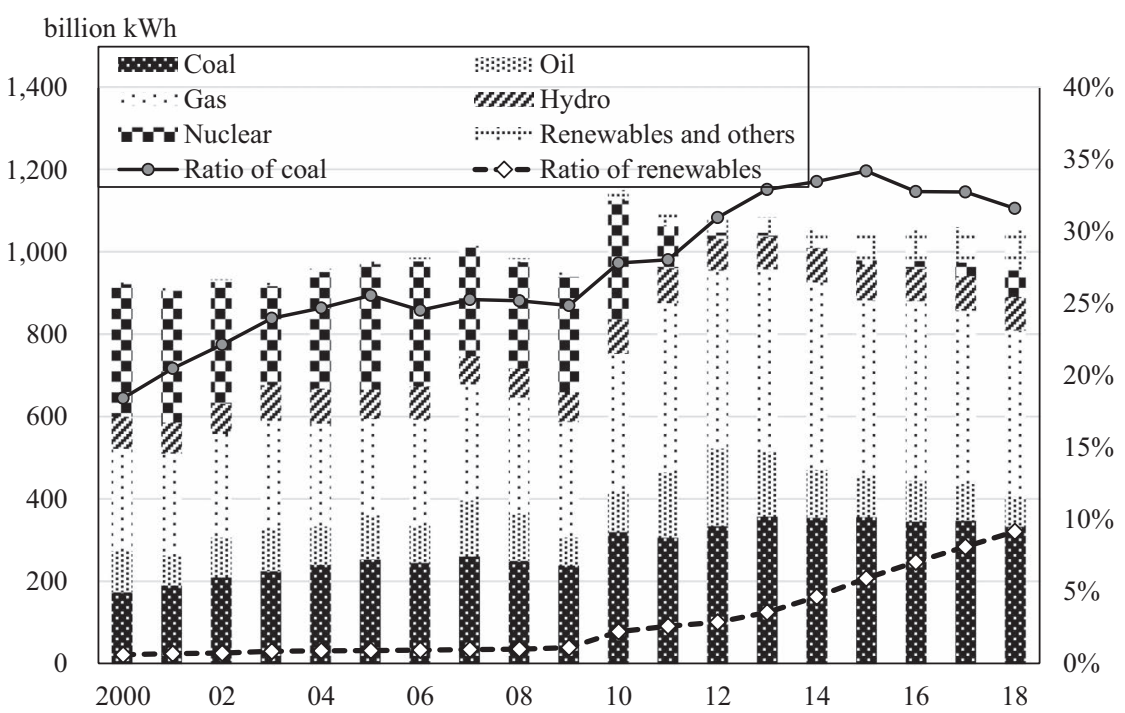

Figure 2.9b Energy mix in power generation in Japan in 2001-2018.

Source: Compiled by the author based on data from Agency for Natural Resources and Energy Japan (2020).

administrative and EIA procedures (Maruyama, 2014), and deference to the incumbent electric power companies for investments in grid capacity and interconnections. These have caused solar curtailment, increased risk of renewable investments, and increased grid access costs. The legally backed priority grid access for the incumbent electricity power companies, and the government's endorsement of their solar curtailment without compensation, further increased risks of investment and grid access costs for RES-E IPPs. The dominance of the incumbent electricity power companies both in the generation and retail market, and insufficient information disclosure collapsed the electricity market in times of emergency, thus disabling independent electricity suppliers, including RES-E producers, from securing stable supply in January 2021 (Hara, 2021). Conversely, incumbent electric power companies are favored in the market design: the capacity remuneration mechanism has been so generous that they can use their obsolete and inefficient fossil fuel power as reserve capacity.

\section{Discussion}

The above-mentioned country case studies indicate three major challenges in the transition from fossil fuel-intensive, vertically integrated, and hierarchical and centrally controlled electricity supply system toward a capitalintensive, distributed, and smart grid-based electricity system that can achieve a large-scale integration of RES-E. 
The first challenge is to tame the incumbent influential regime actors. They are likely to be hit hardest and to lose vested interests, and thus use ample resources to oppose restructuring. In particular, coal and nuclear power generators, coalminers, and dedicated transport companies whose assets have long remaining economic life will protest most fiercely to avoid their assets becoming stranded. In case they are vertically integrated electric power suppliers and dominant in supply, they are likely to work with the government to keep institutional and infrastructural complementarities favoring fossil fuel and nuclear power. These complementarities include investment and consumption subsidies; conservative RES-E generation and renewable purchase obligation targets; priority grid access under utility's monopolistic supply (Yamaka, 2018); curtailment without compensation (Agency for Natural Resources and energy, 2018); and deterred investments in grid capacity and interconnectivity of transmission networks. Some utilities may not address timeliness and reliability of payments for power purchase by state utilities (Chawla et al., 2018), imposing higher investment risks to RES-E generators than coal and gas power providers. Perceiving stagnant future demand, they become reluctant to renovate fossil fuel-based power plants, leaving severe environmental pollution unaddressed.

The second challenge is to reconcile three compelling narratives: "energy for development," that privileges energy as critical to economic growth and long-term strategic security; "energy for industrial development," that fosters the renewable energy industry as a new engine of industrial development; and "energy for all," that prioritizes the role of energy for basic development and ending poverty (Mohan and Topp, 2018; Mori, 2018a). Reverse and competitive auctions have shown effectiveness in the rapid reduction of LCOE and deployment of wind and solar power. However, it can drive out domestic manufacturers and increase international dependence. Further decrease in capital cost and improvements in operation and maintenance can be hardly anticipated in case international suppliers are cartelized and a lack of domestic capacity for commercially deployed renewable energy technology and inadequate built-up capacity are kept unaddressed (Kumar and Majid, 2020). On the other hand, a high local content requirement, limited foreign ownership, and users' preferences for reliable RES generation systems hike the system cost, retarding uptake of RES-E (PwC, 2018) or triggering repercussions from exporting countries (Miles, 2019). A high FiT and priority on utility scale and on-grid RES-E may reconcile the tradeoff but can reduce financial options for small and distributed renewable energy initiatives (Setyowani, 2021). Even such small and distributed initiatives can generate energy injustice by passing through the incremental costs to those consumers who do not have access to the initiatives.

The final challenge is high uncertainty about effectiveness, efficiency, and equity of a capital-intensive, distributed, and network-based electricity 
system, and those in a transition process. Although several countries such as Germany are going ahead in the transition, they have not yet proved the arrangements and elements of complementarities that ensure effectiveness, efficiency, equity, and sustainability of the novel system. Nonetheless, the transition absolutely requires huge amounts of complementary investments, innovative organizational, financial, and institutional arrangements, and restructuring of elements of complementarities that have significant distributional implications.

International actors can accelerate and retard the restructuring. China has provided subsidized financial capital, engineering, manufacturing, and organizational capabilities for coal power in a package, strengthening complementarities in a coal power-based electricity system (Burke et al., 2019; Mori, 2020). International wind and solar power manufacturers, especially Chinese ones, have played a critical role in declining system costs for RES-E.

\section{Conclusions}

The change in energy mix in electricity generation from fossil fuel to renewable energy is accompanied by a transformation of electricity systems from fossil fuel-intensive, centrally controlled toward capital-intensive, distributed, and network-based electricity systems. Achieving this transformation goes beyond addressing each type of lock-in separately to restructuring the interdependence of generation and transmission subsystems and fostering collaboration among key stakeholders.

Against this backdrop, this chapter proposes restructuring of elements of complementarities within and across an electricity system as an analytical framework, exploring how Asian countries have struggled with the restructuring, taking Vietnam, Indonesia, India, and Japan as cases. We find that all four case study countries have struggled with the three challenges of resistance from influential incumbent regime actors, compelling narratives of "energy for development," "energy for industrial development," and "energy for all," and unclear and uncertain benefits from the transformation. Coupled with favorable institutions and infrastructure, and easier access to financial capital, engineering, manufacturing, and organizational capabilities for coal power globally, and less uncertainty in coal power technologies, these challenges can incentivize incumbent regime actors to retard the restructuring, causing renewable curtailment and reducing renewable investments. This is especially the case when international actors support to reinforce the incumbent regime.

It is worth investigating how domestic and foreign actors interact to accelerate or retard the restructuring through investments and trade, and meet the compelling quests for energy security, industrial development, energy justice, and climate requirements. 


\section{References}

Abrishambaf, O., Lezama, F., Faria, P., Vale, Z., 2019. Towards transactive energy systems: An analysis on current trends, Energy Strategy Rev. 26, 100418, https:// doi.org/10.1016/j.esr.2019.100418.

Agency for Natural Resources and energy, 2018. Renewable curtailment for a largescale integration of RES-E, (in Japanese), https://www.enecho.meti.go.jp/about/ special/johoteikyo/kyushu_syuturyokuseigyo.html/, [accessed 25 January 2021].

Aguirre, M., Ibikunle, G., 2014. Determinants of renewable energy growth: A global sample analysis, Energy Policy 69, 374-384, https://doi.org/10.1016/ j.enpol.2014.02.036.

Auer, H., Haas, R., 2016. On integrating large shares of variable renewables into the electricity system, Energy 115, 1592-1601, https://doi.org/10.1016/ j.energy.2016.05.067.

Baker, L., Newell, P., Phillips, J., 2014. The political economy of energy transitions: The case of South Africa, New Polit. Econ. 19(6), 791-818, https://doi.org/10.1080/ 13563467.2013.849674.

Bauknecht, D., Andersen, A.D., Dunne, K.T., 2020. Challenges for electricity network governance in whole system change: Insights from energy transition in Norway, Environ. Innov. Soc. Trans. 37, 318-331, https://doi.org/10.1016/ j.eist.2020.09.004

Beardsworth, J.J. Jr., Schmidt, J.A., 2014. Resource financed infrastructure: Origins and issues, In: Halland, H., J. Beardsworth, B. Land, and J. Schmidt, Resource Financed Infrastructure: A Discussion on a New Form of Infrastructure Financing, The World Bank: Washington DC, 11-68, http://dx.doi.org/10.1596/978-1-4648-0239-3.

Best, R., 2017. Switching towards coal or renewable energy? The effects of financial capital on energy transitions, Energy Econ. 63, 75-83, http://dx.doi.org/10.1016/ j.eneco.2017.01.019.

Bhagwat, P.C., Marcheselli, A., Richstein, J.C., Chappin, E.J.L., De Vries, L.J., 2017. An analysis of a forward capacity market with long-term contracts, Energy Policy 111, 255-267, http://dx.doi.org/10.1016/j.enpol.2017.09.037.

Blakers, A., Stocks, M., Lu, B., Cheng C., Nadolny, A., 2018. Global pumped hydro atlas. http://re100.eng.anu.edu.au/global/index.php/, [accessed 9 February, 2021].

Breu, M., Castellano, A., Frankel, D., Rogers, M., 2019. Exploring an alternative pathway for Vietnam's energy future, https:/www.mckinsey.com/ featured-insights/asia-pacific/exploring-an-alternative-pathway-for-vietnamsenergy-future/, [accessed 5 February, 2021].

Bublitz, A., Keles, D., Zimmermann, F., Fraunholz, C., Fichtner, W., 2019. A survey on electricity market design: Insights from theory and real-world implementations of capacity remuneration mechanisms, Energy Econ. 80, 1059-1078, https:// doi.org/10.1016/j.eneco.2019.01.030.

Burger, S., Chaves-Ávila, J.P., Batlle, C., Pérez-Arriaga, I.J., 2017. A review of the value of aggregators in electricity systems, Renew. Sust. Energ. Rev. 77, 395-405, https://doi.org/10.1016/j.rser.2017.04.014.

Burgholzer, B., Auer, H., 2016. Cost/benefit analysis of transmission grid expansion to enable further integration of renewable electricity generation in Austria, Renew. Energy 97, 189-196, https://doi.org/10.1016/j.renene.2016.05.073.

Burke, P.J., Widnyana, J., Anjum, Z., Aisbett, E., Resosudarmo, B., Baldwin, K.G.H., 2019. Overcoming barriers to solar and wind energy adoption in two 
Asian giants: India and Indonesia, Energy Policy 132, 1216-1228, https://doi. org/10.1016/j.enpol.2019.05.055.

Camarinha-Matos, L.M., 2016. Collaborative smart grids - a survey on trends, Renew. Sustain. Energy Rev. 65, 283-294, https://doi.org/10.1016/j.rser.2016.06.093.

Carl, J., 2015. The causes and implications of India's coal production shortfall, In: Thurber, M.C. and R.K. Morse (eds.) The Global Coal Market: Supplying the Major Fuel for Emerging Economies, Cambridge University Press, Cambridge, 294-373.

Chandra, R., 2011. India's coal-ed streak, Center for the Advanced Study of India, University of Pennsylvania, https://casi.sas.upenn.edu/iit/rohitchandra/, [accessed 28 November 2019].

Chawla, K., Waldron, M., Dutt, A., Aggarwal, M., Toril, A., Nobuoka, Y., 2018. Clean Energy Trends: Evolving Investment Landscape for Grid-Connected Renewable Energy Projects in India. New Delhi: Council on Energy, Environment and Water, https://www.ceew.in/sites/default/files/CEEW-IEA-Clean-EnergyInvestment-Trends-Report-PDF-30Jul18.pdf/, [accessed 3 February 2021].

Colak, I., Sagiroglu, S., Fulli, G., Yesilbudak, M., Covrig, C.F., 2016. A survey on the critical issues in smart grid technologies, Renew. Sustain. Energy Rev. 54, 396-405, https://doi.org/10.1016/j.rser.2015.10.036.

Cramton, P., Ockenfels, A., 2012. Economics and design of capacity markets for the power sector. Zeitschrift für Energiewirtschaft 36, 113-134, https://doi. org/10.1007/s12398-012-0084-2.

Dibyanshu, Rastogi, S., 2020. India: Waiver of inter-state transmission charges and losses (25 August 2020), Khaitan \& Co, https://www.mondaq.com/india/ renewables/979040/waiver-of-inter-state-transmission-charges-and-losses/, [accessed 3 February 2021].

Do, T.N., Burke, P.J., Baldwin, K.G.H., Nguyen, C.T., 2020. Underlying drivers and barriers for solar photovoltaics diffusion: The case of Vietnam, Energy Policy 144, 111561, https://doi.org/10.1016/j.enpol.2020.111561.

Dobrotkova, Z., Surana, K., Audinet, P., 2018. The price of solar energy: Comparing competitive auctions for utility-scale solar PV in developing countries, Energy Policy 118, 133-148, https://doi.org/10.1016/j.enpol.2018.03.036.

Dutt, A., Arboleya, L., Mahadevan, B., 2019. Clean Energy Investment Trends: Evolving Risk Perceptions for India's Grid-Connected Renewable Energy Projects. New Delhi; Paris: Council on Energy, Environment and Water; International Energy Agency, https://www.ceew.in/sites/default/files/CEEW-Clean-EnergyInvestment-Trends-2019.pdf/, [accessed 3 February 2021].

Ela, E., Milligan, M., Bloom, A., Botterud, A., Townsend, A., Levinc, T., Frew, B.A., 2016. Wholesale electricity market design with increasing levels of renewable generation: Incentivizing flexibility in system operations, The Electricity J. 29, 51-60, http://dx.doi.org/10.1016/j.tej.2016.05.001.

Federation of Electric Power Companies of Japan, 2019, FEPC Inforbase 2019, https://www.fepc.or.jp/library/data/infobase/pdf/infobase2019.pdf, [accessed 24 October 2020].

George, A.L., Bennett, A., 2004. Case Studies and Theory Development in the Social Sciences, MIT Press, Cambridge.

Government of Vietnam, 2020. Decision 13/2020/QD-TTg on Mechanism for Encouragement of the Development of Solar Power in Vietnam, Government of Vietnam, Hanoi, Vietnam. 
Gulagi, A., Bogdanov, D., Breyer, C., 2018. The role of storage technologies in energy transition pathways towards achieving a fully sustainable energy system for India, J. Energy Storage 17, 525-539, https://doi.org/10.1016/j.est.2017.11.012.

Hamdi, E., 2019. Indonesia's solar policies: designed to fail? IEEFA report, https:// ieefa.org/wp-content/uploads/2019/02/Indonesias-Solar-Policies_February-2019. pdf/, [accessed 28 January 2021].

Hansen, E.G., Lüdeke-Freund, F., Quan, X.I., West, J., 2019. Cross-national complementarity of technology push, demand pull, and manufacturing push policies: The case of photovoltaics, IEEE T Eng. Manage. 66:3, 381-397, https://doi.org/ 10.1109/TEM.2018.2833878.

Hara, E. 2021. Japan's crisis after the "confusion in the electricity market," $J B$ Press (6 February 2021), (in Japanese), https://jbpress.ismedia.jp/articles/-/63972/, [accessed 6 February 2021].

Haselip J., Desgain, D., Mackenzie, G., 2013. Financing energy SMEs in Ghana and Senegal: Outcomes, barriers and prospects, Energy Policy 65, 369-376, https://doi. org/10.1016/j.enpol.2013.10.013.

Haskel, J., Westlake, S., 2018. Capitalism without Capital: The Rise of the Intangible Economy, Princeton University Press, Princeton.

Haukkala, T., Holttinen, H., Kiviluoma, J., Mori, A., Penttinen, S.L., Kilpeläinen, S., Talus, K., Aalto, P., 2021. How to accelerate renewable energy production? In: Aalto P. (ed.) Electrification: Accelerating the Energy Transition, Academic Press and Elservier, 79-93, https://doi.org/10.1016/B978-0-12-822143-3.00002-0.

Hirth, L., Ueckerdt, F., Edenhofer, O., 2015. Integration costs revisited-An economic framework for wind and solar variability, Renew. Energy 74, 925-939, https://doi.org/10.1016/j.renene.2014.08.065.

Honma, R. 2016. Nuclear Power Propaganda, Iwanami Shinsho, Tokyo (in Japanese).

International Energy Agency (IEA), 2013. Redrawing the Energy-Climate Map, https://webstore.iea.org/download/direct/480/, [accessed 25 January 2021].

IEA, 2019. Southeast Asia Energy Outlook 2019/, https://www.iea.org/reports/ southeast-asia-energy-outlook-2019, [accessed 26 September 2020].

IEA, 2021. IEA Data and Statistics, https://www.iea.org/data-and-statistics/datatables?country $=$ CHINAREG\&energy $=$ Electricity \&year $=2019 /$, [accessed 8 January 2021].

International Hydropower Association, 2018. 2018 Hydropower Status Report: Sector Trends and Insights, https://hydropower-assets.s3.eu-west-2.amazonaws.com/ publications-docs/iha_2018_hydropower_status_report_4.pdf/, [accessed 9 January 2021].

International Hydropower Association, 2019. 2019 Hydropower Status Report: Sector Trends and Insights, https://hydropower-assets.s3.eu-west-2.amazonaws.com/ publications-docs/2019_hydropower_status_report_0.pdf/, [accessed 9 January 2021].

International Hydropower Association, 2020. 2020 Hydropower Status Report: Sector Trends and Insights, https://hydropower-assets.s3.eu-west-2.amazonaws.com/ publications-docs/2020_hydropower_status_report.pdf/, [accessed 9 January 2021].

IRENA, 2020. Renewable Power Generation Costs in 2019, International Renewable Energy Agency, Abu Dhabi, https://www.irena.org/-/media/Files/IRENA/ Agency/Publication/2020/Jun/IRENA_Power_Generation_Costs_2019.pdf/, [accessed 14 January 2021]. 
Jordan, A., Matt, E., 2014. Designing policies that intentionally stick: Policy feedback in a changing climate, Policy Science 47, 227-247, https://doi.org/10.1007/ s11077-014-9201-x.

Kale, S.S., Dubash, N.K., Bharvirkar, R., 2018. Introduction: A framework for mapping power. In: Dubash, N.K., Kale, S.S., Bharvirkar R. (eds.) Mapping Power: The Political Economy of Electricity in India's States, Oxford University Press, Oxford, 1-27.

Kementerian Energi dan Sumber Daya Mineral, Statistik Ketenagalistrikan Dan Energi, Tahun 2005, 2009, 2012, 2013, 2014 2015, 2016, 2017, 2018, 2019, Jakarta, http://gatrik.esdm.go.id/frontend/download_index/?kode_category=statistik/ [accessed 10 February 2021].

Kennedy, S.F., 2018. Indonesia's energy transition and its contradictions: Emerging geographies of energy and finance, Energy Res. Soc. Sci. 41, 230-237, https://doi. org/ 10.1016/j.erss.2018.04.023.

Kubota, H., Hondo, H., Hienuki, S., Kaieda, H., 2013. Determining barriers to developing geothermal power generation in Japan: Societal acceptance by stakeholders involved in hot springs, Energy Policy 61, 1079-1087, https://doi. org/10.1016/j.enpol.2013.05.084

Kumar, C.R.J., Majid, M.A., 2020. Renewable energy for sustainable development in India: Current status, future prospects, challenges, employment, and investment opportunities, Energy Sustain. Soc. 10:2, https://doi.org/10.1186/ s13705-019-0232-1.

Lehmann, P., Brandt, R., Gawel, E., Heim, S., Korte, K., Löschel, A., Massier, P., Reeg, M., Schober, D., Wassermann, S., 2015. Capacity payments to secure electricity supply? On the future of Germany's power market design, Energy, Sustain. Soc. 5:15, 1-7, https://doi.org/10.1186/s13705-015-0039-7.

Lipari, G., Rosario, G.D., Corchero, C., Ponci, F., Monti, A., 2018. A real-time commercial aggregator for distributed energy resources flexibility management, Sustain. Energy, Grids Netw. 15, 63-75, https://doi.org/10.1016/j.segan.2017. 07.002 .

Lockwood, M., Mitchell, C., Hoggett, R., 2019. Unpacking 'regime resistance' in low-carbon transitions: The case of the British Capacity Market, Energy Res. Soc. Sci. 58, 101278, https://doi.org/10.1016/j.erss.2019.101278.

Luong, P.J., Weinthal, E., 2010. Oil is not a Curse: Ownership Structure and Institutions in Soviet Successor States, Cambridge University Press, Cambridge.

Madrigal, M., Stoft, S., 2012. Transmission Expansion for Renewable Energy Scale-Up: Emerging Lessons and Recommendations, A World Bank Study. World Bank, Washington, DC, http://hdl.handle.net/10986/9375/, [accessed 14 January 2021].

Markard, J., Hoffmann, V.H., 2016. Analysis of complementarities: Framework and examples from the energy transition, Technol. Forecast. Soc. Change 111, 63-75, http://dx.doi.org/10.1016/j.techfore.2016.06.008.

Markard, J., Wirth, S., Truffer, B., 2016. Institutional dynamics and technology legitimacy - A framework and a case study on biogas technology, Res. Policy 45, 330-344, https://doi.org/10.1016/j.respol.2015.10.009.

Maruyama, Y. 2014. Socialization of Renewable Energy: Revisiting Renewable Energy from Social Acceptance, Yuhikaku: Tokyo (in Japanese).

Meadowcroft, J., 2011. Engaging with the politics of sustainability transitions, Environ. Innov. Soc. Trans 1(1), 70-75, https://doi.org/10.1016/j.eist.2011.02.003. 
Miles, T., 2019. India wins U.S. solar case at WTO but impact disputed, (28 June 2019), https://www.reuters.com/article/us-usa-trade-india-wto-idUSKCN1TS 2B0/, [accessed 2 February 2021].

Ministry of Power, 2020. Power Sector at a Glance ALL INDIA, https://powermin. nic.in/en/content/power-sector-glance-all-india/, [accessed 3 February 2021].

Mohan, A., Topp, K., 2018. India's energy future: Contested narratives of change, Energy Res. Soc. Sci. 44, 75-82, https://doi.org/10.1016/j.erss.2018.04.040.

Mori, A., 2018a. Climate-energy policy: Domestic policy process, outcome and impacts. In: Mori, A. (ed.) China's Climate-Energy Policy: Domestic and International Impacts, Routledge, Abingdon, 3-19, https://doi.org/10.4324/978135 1037587-1.

Mori, A., 2018b. Impact of the China-induced coal boom in Indonesia: A resource governance perspective. In: Mori, A. (ed.) China's Climate-Energy Policy: Domestic and International Impacts, Routledge, Abingdon, 167-197.

Mori, A., 2018c. Sociotechnical and political economy perspectives in the Chinese energy transition, Energy Res. Soc. Sci. 35, 29-36, https://doi.org/10.1016/ j.erss.2017.10.04.

Mori, A., Dong. L., 2018. Impact of the resource boom in the 2000s on Asian-Pacific energy exporting countries. In: Mori, A. (ed.) China's Climate-Energy Policy: Domestic and International Impacts, Routledge, Abingdon, 123-153, https://doi. org/10.4324/9781351037587-8.

Mori, A., 2019. Temporal dynamics of infrasystem transition: The Case of Electricity System Transition in Japan, Technol. Forecast. Soc. Change 145, 186-194, https://doi.org/10.1016/j.techfore.2017.05.00.

Mori, A., 2020, Foreign actors, faster transitions? Co-evolution of complementarities, perspectives and sociotechnical systems in the case of Indonesia's electricity supply system, Energy Res. Soc. Sci. 69, 101594, https://doi.org/10.1016/ j.erss.2020.101594.

Mukherjee, S., Chakraborty, D., 2015. Walking a thin line between growth and development concerns? Environmental governance in India. In: Mukherjee, S. and D. Chakraborty (eds.) Environmental Challenges and Governance: Diverse Perspectives from Asia. Routledge, Abingdon, 49-74.

Neefjes, K., Dang, T.T.H., 2017. Towards a socially just energy transition in Vietnam, http://library.fes.de/pdf-files/bueros/vietnam/13684.pdf/, [accessed 4 February 2021].

Negro, S.O., F. Alkemade, M.P. Hekkert, 2012. Why does renewable energy diffuse so slowly? A review of innovation system problems, Renew. Sust. Energ. Rev. 16, 3836-3846, https://doi.org/10.1016/j.rser.2012.03.043.

Neuhoff, K, Barquin, J., Bialek, J.W., Boyd, R., Dent, C.J., Echavarren, F., Grau, T., von Hirschhausen, C., Hobbs, B.F., Kunz, F., Nabe, C., 2013. Renewable electric energy integration: Quantifying the value of design of markets for international transmission capacity, Energy Econ. 40, 760-772, https://doi.org/10.1016/ j.eneco.2013.09.004.

Newbery, D., Pollitt, M.G., Ritz, R.A., Strielkowski, W., 2018. Market design for a high-renewables European electricity system, Renew. Sustain. Energy Rev. 91, 695-707, https://doi.org/10.1016/j.rser.2018.04.025.

Nguyen, L., Kinnucan, H.W., 2019. The US solar panel anti-dumping duties versus uniform tariff, Energy Policy 127, 523-532, https://doi.org/10.1016/j. enpol.2018.11.048 
Nuclear Energy Agency, 2011. Technical and Economic Aspects of Load Following with Nuclear Power Plants, OECD, Paris, https://www.oecd-nea.org/ndd/ reports/2011/load-following-npp.pdf/, [accessed 13 January 2021].

Ode, K.A., Wadin, J.L., 2019. Business model translation-The case of spreading a business model for solar energy, Renew. Energy 133, 23-31, https://doi. org/10.1016/j.renene.2018.09.036.

PwC. 2018. Power in Indonesia: Investment and Taxation Guide, November 2018, 6th edition, https://www.pwc.com/id/en/publications/assets/eumpublications/ utilities/power-guide-2018.pdf/, [accessed 6 April 2019].

REN21, 2018. Renewables 2018 Global Status Report, https://www.ren21.net/wpcontent/uploads/2019/08/Full-Report-2018.pdf/, [accessed 9 February 2021].

REN21, 2020. Renewables 2020 Global Status Report, https://www.ren21.net/ wp-content/uploads/2019/05/gsr_2020_full_report_en.pdf/, [accessed 9 February 2021].

Reshetova, E., 2019. Indonesia's energy transition: From oil to coal, Georgetown J. Asian Affairs Winter 2019, 18-24, http://hdl.handle.net/10822/1053160.

Rifkin, J. 2019. The Green New Deal: Why the Fossil Fuel Civilization Will Collapse by 2028, and the Bold Economic Plan to Save Life on Earth, St. Martins Press, London.

Schmidt, T.S., Matuo, T., Michaelowa, A., 2017. Renewable energy policy as an enabler of fossil fuel subsidy reform? Applying a socio-technical perspective to the cases of South Africa and Tunisia, Global Environ. Change 45, 99-110, http://dx. doi.org/10.1016/j.gloenvcha.2017.05.004.

Schwenen, S., 2015. Strategic bidding in multi-unit auctions with capacity constrained bidders: The New York capacity market, RAND J. Econ. 46:4, 730-750, https://doi.org/10.1111/1756-2171.12104.

Seto, K.C., Davis, S.J., Mitchell, R.B., Stokes, E.C., Unruh, G., Ürge-Vorsatz, D., 2016. Carbon lock-in: Types, causes, and policy implications, Annu. Rev. Environ. Resour. 41, 425-452, https://doi.org/ 10.1146/annurev-environ-110615-085934.

Setyowati, A.B., 2020. Mitigating energy poverty: Mobilizing climate finance to manage the energy trilemma in Indonesia, Sustainability 12: 1603, https://doi. org/10.3390/su12041603.

Setyowati, A.B., 2021. Mitigating inequality with emissions? Exploring energy justice and financing transitions to low carbon energy in Indonesia, Energy Res. Soc. Sci. 71, 101817, https://doi.org/10.1016/j.erss.2020.101817.

Shani, N., 2020. ASEAN solar sector: 2019 Highlights, ASEAN Centre for Energy, https://aseanenergy.org/asean-solar-sector-2019-highlights/, [accessed 4 February 2021].

Siano, P. 2014. Demand response and smart grids-A survey, Renew. Sustain. Energy Rev. 30, 461-478, https://doi.org/10.1016/j.rser.2013.10.022.

Steffen, B., Matsuo, T., Steinemann, D., Schmidt, T.S., 2018. Opening new markets for clean energy: The role of project developers in the global diffusion of renewable energy technologies, Bus. Polit. 20:4, 553-587, https://doi.org/10.1017/ bap.2018.17.

Stirling, A., 2014. Transforming power: Social science and the politics of energy choices, Energy Res. Soc. Sci. 1, 83-95, https://doi.org/10.1016/j.erss.2014.02.001.

Tarai, R.K., Kale, P., 2018. Solar PV policy framework of Indian States: Overview, pitfalls, challenges, and improvements, Renew. Energy Focus 26, 46-57, https:// doi.org/10.1016/j.ref.2018.07.001. 
Thapar, S., Sharma, S., Verma, A., 2018. Analyzing solar auctions in India: Identifying key determinants, Energy Sustain. Dev. 45, 66-78, https://doi.org/10.1016/ j.esd.2018.05.003.

The Economic Times, 2019. India levies anti-dumping duty on solar cell component from four nations, (1 April 2019), https://economictimes.indiatimes. $\mathrm{com} /$ news/economy/foreign-trade/india-levies-anti-dumping-duty-on-solarcell-component-from-four-nations/articleshow/68668956.cms?utm_source= contentofinterest\&utm_medium=text\&utm_campaign=cppst/, [accessed 25 January 2021].

Torriti, J. 2016. Peak Energy Demand and Demand Side Response, Routledge, Abingdon.

Tushman, M.L., Rosenkopf, L., 1992. Organizational determinants of technological change: Toward a sociology of technological evolution, Res. Organ. Behav. 14, 311-347.

Vietnam Electricity (EVN), Corporate Profile 2010/11, 2011/12, 2012/13, 2015, 2016, 2017, 2018, https://en.evn.com.vn/d6/news/-Annual-Report-2018-6-13-2118.aspx/, [accessed 10 February 2021].

Vishwanathan, S.S., Garg, A., Tiwari, V., 2018. Coal transition in India: assessing India's energy transition options, IDDRI and Climate Strategies, https://www. iddri.org/sites/default/files/PDF/Publications/Catalogue\%20Iddri/Rapport/ 20180609_ReportCOAL_India.pdf/, [accessed 2 February 2021].

West Japan Engineering Consultants, Inc., 2007. The barriers of geothermal development and necessity of government support. In: Master Plan Study for Geothermal Power Development in the Republic of Indonesia Final Report, Japan International Cooperation Agency and Ministry of Energy and Mineral Resources of the Republic of Indonesia, https://openjicareport.jica.go.jp/pdf/11864576_05.pdf/, [accessed on 10 January 2019].

World Bank, 2019. Vietnam Solar Competitive Bidding Strategy and Framework. World Bank, Washington, DC, http://documents1.worldbank.org/curated/ en/949491579274083006/pdf/Vietnam-Solar-Competitive-Bidding-Strategy-andFramework.pdf/, [accessed 5 February 2021].

World Bank, 2020. World Development Indicators (Last Updated 16 December 2020), https://databank.worldbank.org/source/world-development-indicators/, [accessed 8 January 2021].

World Business Council for Sustainable Development (WBCSD), 2016. Corporate renewable power purchase agreements: Scaling up globally, https://www.wbcsd. org/contentwbc/download/1810/22670/, [accessed 17 January 2021].

Yamaka, K., 2018. The Problem of No Vacant Grid Capacity: Electricity Market Is Not Liberalized in Practice in Japan, NextPublsihing (in Japanese).

Yamaoka, J., 2015. Japan's Electricity War: History of Struggles over Resources, Interests and Nuclear Power, Soushisha, Tokyo) (in Japanese).

Zimmer, A., Jakob, M., Steckel, J.C., 2015. What motivates Vietnam to strive for a low-carbon economy? - On the drivers of climate policy in a developing country, Energy Sustain. Dev. 24, 19-32, http://dx.doi.org/10.1016/j.esd.2014.10.003. 